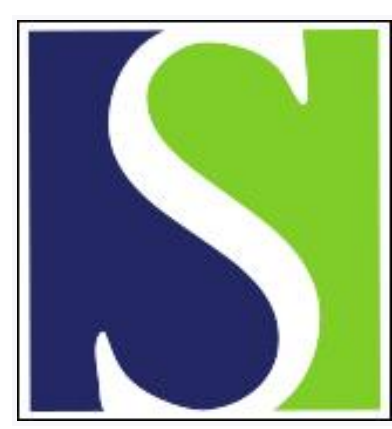

Scand J Work Environ Health 1997;23(6):421-427

https://doi.org/10.5271/sjweh.264

Issue date: Dec 1997

Respiratory symptoms, spirometry and chronic occupational paraquat exposure

by Castro-Gutiérrez N, McConnell R, Andersson K, Pacheco-Antón F, Hogstedt C

Key terms: dyspnea; herbicide; pesticide; spirometry; wheezing 


\title{
Respiratory symptoms, spirometry and chronic occupational paraquat exposure
}

\author{
by Néstor Castro-Gutiérrez, MD, Rob McConnell, MD, ${ }^{2}$ Kjell Andersson, MD, ${ }^{3}$ \\ Feliciano Pacheco-Antón, MD, ${ }^{4}$ Christer Hogstedt, $M D^{5}$
}

\begin{abstract}
Castro-Gutiérrez N, McConnell R, Andersson K, Pacheco-Antón F, Hogstedt C. Respiratory symptoms, spirometry and chronic occupational paraquat exposure. Scand J Work Environ Health 1997;23(6):421-7.

Objectives A cross-sectional study was conducted to evaluate the relationship between respiratory health and paraquat exposure.

Methods The study population was selected from among workers at 15 Nicaraguan banana plantations which relied on paraquat for the control of weeds. All the workers were interviewed after they received their job assignment for the day of the survey, and all who reported never having applied paraquat and all who reported more than 2 years of cumulative exposure as applicators of paraquat with knapsack sprayers were invited for medical evaluation. One hundred and thirty-four exposed workers and 152 unexposed workers were administered a questionnaire interview asking about exposure and respiratory symptoms, and they underwent spirometric testing of forced expiratory volume in $1 \mathrm{~s}\left(\mathrm{FEV}_{1.0}\right)$ and forced vital capacity $(\mathrm{FVC})$.

Results In the exposed group 53\% reported having experienced a skin rash or burn resulting from paraquat exposure, $25 \%$ reported epistaxis, $58 \%$ nail damage, and $42 \%$ paraquat splashed in the eyes. There was a consistent dose-response relationship between intensity of exposure (as indicated by a history of skin rash or burn) and the prevalence of dyspnea. This relationship was more marked for more severe dyspnea. There was a 3 -fold increase in episodic wheezing accompanied by shortness of breath among the more intensely exposed workers. There was no relationship between exposure and FEV ${ }_{10}$ or FVC.

Conclusions The high prevalence of respiratory symptoms associated with exposure, in the absence of spirometric abnormalities associated with exposure, could be a result of unmeasured gas exchange abnormalities among workers with long-term exposure to paraquat.
\end{abstract}

Key terms dyspnea, herbicides, pesticides, spirometry, wheezing.

Paraquat, a nonselective contact herbicide used in approximately 130 countries (1), is widely available to as much as $98 \%$ of agricultural workers in third-world countries (2). Paraquat has become well known for its acute oral toxicity. A review published in 1974 reported 232 deaths world-wide between 1964 and 1973 (3). By 1985 almost 2000 deaths were occurring yearly in Japan alone as a result of (primarily intentional) ingestion of paraquat (4). In reports from Asia, the Pacific Islands, and South America, it is the agent of choice for suicide (4-6). In Costa Rica, a country with one of the highest incidences of pesticide poisoning in the world, paraquat causes more deaths than any other pesticide, including $86 \%$ of all deaths from occupational pesticide poisoning (7). Almost half of all fatal paraquat poisonings in Costa Rica are not intentional.

The case fatality rate after the ingestion of liquid formulations of $20 \%$ paraquat is reported to be $60 \%$, and the minimum lethal dose may be no more than $10 \mathrm{ml}(8)$. Paraquat is unusual in that it concentrates in vivo and in vitro in lung tissue in experimental animals.(9) It produces acute pulmonary edema and dense intraalveolar pulmonary fibrosis (perhaps mediated by the formation of superoxide radicals) in patients who do not succumb

1 Department of Preventive Medicine, National Autonomous University of Nicaragua, León, Nicaragua.

2 Department of Preventive Medicine, University of Southern California, Los Angeles, California, the United States.

3 Environmental and Occupational Medicine, Orebro Medical Center Hospital, Orebro, Sweden.

4 Ministry of Health, León, Nicaragua.

5 National Institute for Working Life, Stockholm, Sweden.

Reprint requests to: Dr Rob McConnell, Division of Occupational and Environmental Medicine, PO Box 1057, Mount Sinai School of Medicine, New York, NY 10029, USA. [e-mail: rmcconne@hsc.usc.edu] 
to acute caustic effects on the gastrointestinal tract or acute renal or hepatic failure (10). Only limited data are available on the pulmonary sequelae among survivors of acute poisoning. However, some reports suggest that fibrosis and pulmonary function abnormalities, especially decreased diffusing capacity, occur among some survivors $(11-15)$.

There have been a few reports of poisoning and death from pulmonary fibrosis as a result of dermal exposure to paraquat (16), including cases which have occurred after the application of dilute paraquat according to label instructions $(17,18)$. In the occupational setting, such cases are probably rare in developed countries, where application is commonly aerial and where workers are more likely to be well protected (19). In developing countries the heaviest occupational dermal exposures occur among workers applying paraquat with knapsack sprayers. Personal protective equipment is often not available, sprayers are poorly serviced, and epistaxis, damage to (and subsequent loss of) fingernails and toenails, and rashes (which would impair the dermal barrier to absorption) are reported to be common $(20-22)$. It is among these heavily exposed workers that systemic poisoning resulting from dermal absorption might occur.

Although undamaged human skin appears to provide protection against diluted paraquat, skin penetration of chemicals, including pesticides, can vary considerably (23). Scrotal skin is 42 times more permeable than forearm skin (24). Experimental damage to human skin (stripping with tape until it glistens) and occlusion and hydration of skin may increase penetration by 20 -fold. Analogs to these experimental procedures occur in the occupational setting. Exposed skin can be occluded and hydrated, for example, by a leaky knapsack sprayer against an applicator's back or by exposure to the axillary or inguinal folds. There is ample evidence that paraquat causes rashes, damaging skin, especially skin of the easily penetrated genitalia, which appears to be especially sensitive to damage upon exposure to paraquat solutions (20, 22, 25-29). Deaths have been reported among rabbits exposed daily to as little as $1.1 \mathrm{mg} / \mathrm{kg}$

Table 1. Relationship between exposure to paraquat and demographic and smoking characteristics of the study population.

\begin{tabular}{|c|c|c|c|c|c|c|}
\hline \multirow[t]{3}{*}{ Exposure group } & \multicolumn{3}{|c|}{ Men } & \multicolumn{3}{|c|}{ Women } \\
\hline & \multirow{2}{*}{$\begin{array}{c}\text { Smokers } \\
(\%)\end{array}$} & \multicolumn{2}{|c|}{ Age } & \multirow{2}{*}{$\begin{array}{c}\text { Smokers } \\
(\%)\end{array}$} & \multicolumn{2}{|c|}{ Age } \\
\hline & & Mean & SD & & Mean & SD \\
\hline $\begin{array}{l}\text { No exposure } \\
(N=152)\end{array}$ & 66 & 37.9 & 9.7 & 19 & 35.3 & 8.2 \\
\hline $\begin{array}{l}\text { Low exposure } \\
\text { ( } N=63 \text { ) } \\
\text { (no rash) }\end{array}$ & 67 & 38.1 & 8.4 & 15 & 31.5 & 4.2 \\
\hline $\begin{array}{l}\text { Intense exposure } \\
(\mathrm{N}=71) \\
\text { (history of rash) }\end{array}$ & 67 & 38.8 & 9.9 & 14 & 33.0 & 6.3 \\
\hline
\end{tabular}

under occlusion (the lowest dose tested)(30). This is less than the total dermal exposures reported in studies of exposed knapsack sprayers (up to $113 \mathrm{mg} / \mathrm{kg}$ in an hour on Central American banana plantations with conditions similar to those of the present study) (31).

It is not known whether chronic, heavy occupational exposure produces chronic pulmonary disease. Based on the chronic effects of acute poisoning, one might expect to see pulmonary fibrosis. However, there have been few epidemiologic studies on this topic. One recent study found no abnormalities in lung function among workers chronically exposed to paraquat (32). Other studies have been flawed by insensitive methods $(20,22)$, small sample sizes (33), or exposures to multiple pesticides (34). The present study is a large cross-sectional evaluation of long-term subacute pulmonary sequelae of paraquat exposure among knapsack sprayers in Nicaragua. The a priori hypothesis of this study was that, among exposed workers, those with a history of skin rash or burn would have been more likely to experience the peak exposures which might produce chronic pulmonary disease.

\section{Population and work practices}

During 1987 and 1988 each of the 15 plantations owned by a large banana exporting company in Northern Pacific Nicaragua was visited. The total number of employees during that period averaged approximately 2300 workers. The plantations relied heavily on paraquat for controlling weeds around the base of the banana plants. A $20 \%$ concentrate was transferred from a 55 gallon drum into unlabeled containers. These containers were carried by teams of $2-6$ workers into the fields, where the concentrate was diluted with water to a $0.1-0.2 \%$ spray solution and applied from knapsack sprayers. Many of the workers carried, mixed, and loaded their own concentrated solutions in the fields, resulting in greater exposures than if they worked only as applicators. Absorption may be further enhanced by the addition of a surface active "wetting agent" to the formulation (35).

The importance of personal protective equipment in preventing skin damage from paraquat has been emphasized by regulatory agencies (36). However, as in much of the developing world, personal protective equipment is unavailable or cannot be used in Nicaragua because of tropical heat (37). Workers wore rubber boots and long pants, short sleeved shirts, and no gloves or respiratory protection.

Paraquat spraying was heaviest during the rainy season from June through December. Workers were assigned full time to paraquat spray teams for periods from a few days to 6 months or more at a time. The women smoked less than the men and were younger than the men in all the exposure groups (table 1). 


\section{Subjects and methods}

All workers present were surveyed as they received job assignments for the day each plantation was visited. All workers 24 years of age or older who reported never having applied paraquat (known in Nicaragua by its trade name Gramoxone ${ }^{\mathrm{TM}}$ ) and all workers who reported having spent a cumulative total of 24 months or more applying paraquat by knapsack sprayer were invited to remain for an interview and spirometric examination. A total of 134 workers (100 men and 34 women) with 2 or more years' exposure to paraquat ( $95 \%$ participation) and 152 ( 88 men and 64 women) who had never applied paraquat ( $92 \%$ participation) were examined.

On the basis of the questionnaire responses, the workers were divided into 3 groups: (i) unexposed workers who reported no history of work with paraquat $(\mathrm{N}=152)$, (ii) exposed participants who reported cumulative exposure as paraquat knapsack sprayers for 24 or more months but no history of rash or skin burn attributed to paraquat exposure $(\mathrm{N}=63)$, and (iii) more intensely exposed workers with at least 24 months of cumulative work as knapsack sprayers who also reported a prior history of rash or skin burn attributed to paraquat $(\mathrm{N}=71)$.

\section{Questionnaire}

Each participating worker was interviewed using a standardized questionnaire modified from the respiratory questionnaire of the British Medical Research Council (38). Outcomes of interest included 3 grades of exertional dyspnea (while walking on an incline or while hurrying - grade 1; while walking with people of the same age on level ground - grade 2; and while walking at one's own pace on level ground - grade 3 ); chronic bronchitis (productive cough for more than 3 months yearly for 2 or more years); and acute, intermittent shortness of breath accompanied by wheezing. In addition, workers were asked about left elbow pain, a symptom unlikely to be related to paraquat exposure, which was included as an indication of possible indiscriminate overreporting.

The participants were also asked about other symptoms previously reported to be associated with paraquat exposure (nail damage or loss of nails, bloody nose, splashes in eyes).

Potential confounders (age and lifetime cumulative smoking history of 20 packs of cigarettes or more) were also identified.

\section{Exposure}

Because more concentrated paraquat or solutions of paraquat in contact with occluded skin may be more likely to cause skin damage and skin damage is known to enhance pesticide absorption, rash or skin burn was used as a surrogate for the intensity of exposure for the pur- pose of evaluating a dose-response relationship between exposure and health outcome.

\section{Spirometry}

All the workers were examined with a Collins watersealed survey spirometer (WE Collins, Braintree, Massachussetts, United States) and by technicians following American Thoracic Society recommendations (39). The instrument was calibrated at the beginning and end of each workday with a 3 -liter syringe. Forced vital capacity (FVC) and forced expiratory volume in 1 second $\left(\mathrm{FEV}_{1.0}\right)$ were measured. Regression formulas for expected values were obtained from a working population of Nicaraguans not exposed to pulmonary toxins (40). Workers with an FVC of $<80 \%$ of the predicted value were classified as having a restrictive defect; participants with an $\mathrm{FEV}_{1.0}: \mathrm{FVC}$ ratio of $<0.70$ were classified as having an obstructive defect.

\section{Analysis}

Univariate and multivariate analyses were conducted using an SPSS-PC program (41). The estimation of relative risks was based on the Mantel-Haenszel procedure (42). The $95 \%$ confidence intervals $(95 \%$ CI) of the odds ratios were calculated according to a method described by Miettinen (43). A logistic regression analysis of the data was also undertaken.

\section{Results}

Among the exposed group of 134 subjects, 53\% reported having experienced a skin rash or burn resulting from paraquat exposure. Epistaxis due to paraquat exposure was reported by $25 \%$, nail damage by $58 \%$, and eyes splashed with paraquat by $42 \%$. Several workers anecdotally reported continued blurred vision, which they attributed to such a splash. One worker was examined who had an opacified cornea as a result of spilling concentrate in his eye. (He was not part of the study population, because he had not worked cumulatively for 2 years or longer with paraquat.)

There was a higher proportion of exposed workers with a history of skin rash or burn reporting a history of nail damage, compared with the exposed workers with no history of skin rash or burn [relative risk (RR) 1.4, 95\% CI 1.1-1.9]. (See table 2.) More intensely exposed workers also reported more epistaxis (RR 2.2, 95\% CI $1.1-4.1)$ and spills affecting eyes (RR 1.4, 95\% CI $0.9-2.1$ ).

Among the exposed workers there was a larger proportion with exertional dyspnea of all grades, especially grade 3 (table 3 ). There was a consistent dose-response relationship between the intensity of exposure and exer- 
tional dyspnea after adjustment for smoking, age, and gender. The prevalence of chronic bronchitis (not statistically significant) and the prevalence of episodic shortness of breath accompanied by wheezing were increased only in the more intensely exposed group (table 4). The risk ratios for the symptoms presented were essentially unchanged after all the subjects who reported left elbow pain, a symptom which would not be expected to be related to paraquat exposure, were excluded from the analysis. Because they did not differ essentially from the stratified analysis, the results of the logistic regression procedure are not presented. There was no evidence of an interaction between age and exposure.

Table 2. History of skin rash or burns in relation to other known effects of paraquat exposure.

\begin{tabular}{|c|c|c|c|c|c|c|}
\hline \multirow[t]{2}{*}{ Group } & \multicolumn{2}{|c|}{ Nail damage } & \multicolumn{2}{|c|}{ Nose bleed } & \multicolumn{2}{|c|}{ Spill in eye } \\
\hline & N & $\%$ & N & $\%$ & $\mathrm{~N}$ & $\%$ \\
\hline $\begin{array}{l}\text { Low exposure } \\
\text { (no rash) } \\
\left(N=63^{a}\right)\end{array}$ & 29 & 48 & 9 & 15 & 21 & 35 \\
\hline $\begin{array}{l}\text { Intense exposure } \\
\text { (history of rash) } \\
\left(\mathrm{N}=71^{\mathrm{a}}\right)\end{array}$ & 48 & 68 & 23 & 33 & 34 & 49 \\
\hline
\end{tabular}

a Number varies slightly by effect because of missing data.
There was no relationship between abnormal spirometric results and exposure (table 4 ), nor was there a consistent decline in FVC (or $\mathrm{FEV}_{1.0}$ ) in relation to exposure (table 5). A history of smoking was associated with a decreased $\mathrm{FEV}_{1.0}$ among the women but not among the men.

\section{Discussion}

The increased prevalence of self-reported exertional dyspnea, episodic shortness of breath accompanied by wheezing, and possibly chronic bronchitis among paraquat-exposed workers suggests an effect of longterm paraquat exposure on respiratory health. In addition, there was a clear dose-response relationship between exposure and exertional dyspnea, the principal symptom of interest because of its association with pulmonary fibrosis. An increased prevalence of episodic shortness of breath with wheezing was seen only among the more intensely exposed group. These observed effects could not be explained by confounding factors or by possible overreporting (represented by the reporting of left elbow pain).

Table 3. Dyspnea among the exposure groups. ( $0 \mathrm{R}=$ odds ratio, $95 \% \mathrm{Cl}=95 \%$ confidence interval)

\begin{tabular}{|c|c|c|c|c|c|c|c|c|c|c|c|c|c|c|}
\hline \multirow[t]{2}{*}{ Group } & \multicolumn{2}{|c|}{$\begin{array}{l}\text { Without } \\
\text { dyspnea }\end{array}$} & \multicolumn{4}{|c|}{ Grade 1 dyspnea } & \multicolumn{4}{|c|}{ Grade 2 dyspnea } & \multicolumn{4}{|c|}{ Grade 3 dyspnea } \\
\hline & $\mathrm{N}$ & $\%$ & $N$ & $\%$ & $O R^{a}$ & $95 \% \mathrm{Cl}$ & $N$ & $\%$ & $0 R^{a}$ & $95 \% \mathrm{Cl}$ & $N$ & $\%$ & $O R^{a}$ & $95 \% \mathrm{Cl}$ \\
\hline $\begin{array}{l}\text { No exposure } \\
\left(N=152^{b}\right)\end{array}$ & 95 & 63 & 25 & 16 & $\cdot$ & . & 11 & 7.2 & $\cdot$ & . & 21 & 14 & , & . \\
\hline $\begin{array}{l}\text { Low exposure } \\
\left(N=63^{\circ}\right)\end{array}$ & 30 & 48 & 7 & 11 & 1.0 & $0.36-2.9$ & 6 & 9.5 & 1.6 & $0.59-4.5$ & 20 & 32 & 2.8 & $1.4-5.6$ \\
\hline $\begin{array}{l}\text { Intense } \\
\text { exposure } \\
\left(\mathrm{N}=71^{\mathrm{b}}\right)\end{array}$ & 26 & 37 & 7 & 10 & 1.1 & $0.39-3.3$ & 7 & 10 & 2.0 & $0.71-5.6$ & 30 & 43 & 4.6 & $2.4-9.0$ \\
\hline
\end{tabular}

a Exposure odds ratio for each grade of dyspnea compared with workers with no dyspnea (adjusted for age, gender, and smoking history).

b Number varies slightly by effect because of missing data.

Table 4. Chronic bronchitis, episodic dyspnea accompanied by wheezing, and abnormal spirometry in the exposure groups. (OR $=$ odds ratio, $95 \% \mathrm{Cl}=95 \%$ confidence interval)

\begin{tabular}{|c|c|c|c|c|c|c|c|c|c|c|c|c|c|c|c|c|}
\hline \multirow[t]{3}{*}{ Group } & \multirow{2}{*}{\multicolumn{4}{|c|}{ Chronic bronchitis }} & \multirow{2}{*}{\multicolumn{4}{|c|}{$\begin{array}{l}\text { Episodic dyspnea with } \\
\text { wheezing }\end{array}$}} & \multicolumn{8}{|c|}{ Spirometry } \\
\hline & & & & & & & & & \multicolumn{4}{|c|}{ Restrictive } & \multicolumn{4}{|c|}{ Obstructive } \\
\hline & N & $\%$ & $O R^{a}$ & $95 \% \mathrm{Cl}$ & N & $\%$ & $O R^{a}$ & $95 \% \mathrm{Cl}$ & N & $\%$ & $O R^{a}$ & $95 \% \mathrm{Cl}$ & N & $\%$ & $O R^{a}$ & $95 \% \mathrm{Cl}$ \\
\hline $\begin{array}{l}\text { No } \\
\text { exposure } \\
\left(N=152^{b}\right)\end{array}$ & 17 & 12 & & & 17 & 11 & & . & 8 & 5.8 & . & . & 11 & 8 & . & . \\
\hline $\begin{array}{l}\text { Low } \\
\text { exposure } \\
\left(N=63^{\circ}\right)\end{array}$ & 8 & 13 & 1.0 & $0.41-2.6$ & 8 & 13 & 0.98 & $0.37-2.6$ & 5 & 8.9 & 1.2 & $0.41-3.7$ & 5 & 8.9 & 0.93 & $0.32-2.7$ \\
\hline $\begin{array}{l}\text { Intense } \\
\text { exposure } \\
\left(N=71^{b}\right)\end{array}$ & 16 & 23 & 2.0 & $0.92-4.4$ & 20 & 28 & 2.9 & $1.4-6.3$ & 1 & 1.6 & 0.16 & $0.02-1.4$ & 9 & 13 & 1.3 & $0.51-3.4$ \\
\hline
\end{tabular}

a Exposure odds ratio adjusted for age, gender, and smoking history.

- Number varies slightly by effect because of missing data. 
Table 5. Regression coefficients for exposure to paraquat and other predictors of forced expiratory volume in $1 \mathrm{~s}\left(\mathrm{FEV}_{1.0}\right)$ and forced vital capacity (FVC).

\begin{tabular}{|c|c|c|c|c|c|c|c|c|}
\hline & \multicolumn{4}{|c|}{$\mathrm{FEV}_{1.0}$} & \multicolumn{4}{|c|}{ FVC } \\
\hline & \multicolumn{2}{|c|}{ Men } & \multicolumn{2}{|c|}{ Women } & \multicolumn{2}{|c|}{ Men } & \multicolumn{2}{|c|}{ Women } \\
\hline & $\begin{array}{l}\text { Regression } \\
\text { coefficient }\end{array}$ & P-value & $\begin{array}{l}\text { Regression } \\
\text { coefficient }\end{array}$ & P-value & $\begin{array}{l}\text { Regression } \\
\text { coefficient }\end{array}$ & P-value & $\begin{array}{c}\text { Regression } \\
\text { coefficient } \\
\text { value }\end{array}$ & P-value \\
\hline Height & 0.033 & $<0.001$ & 0.021 & 0.004 & 0.053 & $<0.001$ & 0.024 & 0.004 \\
\hline Age & -0.023 & $<0.001$ & -0.026 & $<0.001$ & -0.011 & .01 & -0.020 & $<0.001$ \\
\hline Smoking & -0.059 & 0.41 & -0.229 & 0.001 & -0.079 & 0.35 & -0.152 & 0.13 \\
\hline $\begin{array}{l}\text { Low exposure } \\
\text { (no rash) }\end{array}$ & -0.068 & 0.43 & -0.018 & 0.83 & -0.077 & 0.45 & 0.003 & 0.98 \\
\hline $\begin{array}{l}\text { High exposure } \\
\text { (history rash) }\end{array}$ & 0.008 & 0.91 & -0.027 & 0.78 & 0.011 & 0.91 & -0.063 & 0.57 \\
\hline
\end{tabular}

The large proportion of chronically exposed paraquat applicators who reported episodes of damage to skin, nails, and nasal mucosa suggests that this was a highly exposed population. Among knapsack sprayers in other parts of the developing world, high rates of nail damage have been reported (19\% of applicators on sugar estates in Trinidad) (21), as have epistaxis and eye splashes (20). Although skin damage has been reported (20, 36, 44 ), there have been no previous studies which have reported the proportion of exposed workers previously affected. The study population demonstrated good internal consistency between the previously reported common effects of paraquat exposure and skin rash or burn (table 2).

Among the unexposed workers in this study, the prevalence of chronic bronchitis (12\%) and intermittent shortness of breath with wheezing $(11 \%)$ was within the range reported in studies conducted in the United States (45) and in other published studies from Nicaragua $(46,47)$. From cross-cultural studies the prevalence of chronic bronchitis is known to vary widely (48). In North American and British populations the prevalence of dyspnea determined according to the questionnaire of the British Medical Research Council is generally lower than the $37 \%$ (grade 1 or above) in unexposed study populations. However, a high prevalence of dyspnea has been reported from other surveys of unexposed workers in Nicaragua and in some surveys of workers and communities unexposed to industrial pollution in the United States and Great Britain (table 6). The relatively high prevalence of dyspnea among unexposed Nicaraguan workers may result from confusion between shortness of breath and fatigue in the tropical heat characteristic of work on a banana plantation. Indeed, the local idiom for shortness of breath is "fatiga", which can also be used to refer to fatigue. It is also possible that dyspnea results from some unidentified exposure in the agricultural environment, which is known to be associated with numerous agents producing respiratory diseases (54). Although the precise interpretation of the clinical significance is unclear, it is apparent that paraquat-exposed workers have more respiratory symptoms than unexposed workers.

A puzzling feature of these results is the lack of a relationship between exposure and objective measurements of pulmonary function. If paraquat exposure were producing symptoms mediated by either obstructive or restrictive disease, one would expect to see corresponding spirometric abnormalities. While it may be that longterm paraquat exposure of the type observed has no effect on lung function, the index which one would expect to be most affected under these circumstances would be diffusing capacity $(11,12)$. Although one recent crosssectional study showed no difference in diffusing capaci-

Table 6. Prevalence of dyspnea reported by workers in a selected review of the literature. (US = United States)

\begin{tabular}{|c|c|c|c|c|}
\hline \multirow[t]{2}{*}{ Author } & \multirow[t]{2}{*}{ Population } & \multicolumn{3}{|c|}{$\begin{array}{l}\text { Percent reporting } \\
\text { dyspnea }\end{array}$} \\
\hline & & Men & Women & Total \\
\hline $\begin{array}{l}\text { Castro-Gutiérrez } \\
\text { et al, } 1997 \\
\text { (present study) }\end{array}$ & $\begin{array}{l}\text { Nicaraguan } \\
\text { plantation } \\
\text { workers }\end{array}$ & 34 & 42 & 37 \\
\hline $\begin{array}{l}\text { Velazquez et al, } \\
1991 \text { (46) }\end{array}$ & $\begin{array}{l}\text { Urban Nicaraguan } \\
\text { workers }\end{array}$ & 14 & 29 & 20 \\
\hline $\begin{array}{l}\text { Quintero et al, } \\
1996 \text { (47) }\end{array}$ & $\begin{array}{l}\text { Urban Nicaraguan } \\
\text { workers }\end{array}$ & & & 36 \\
\hline $\begin{array}{l}\text { Wilcox, } \\
\text { unpublished datat }\end{array}$ & $\begin{array}{l}\text { Urban Nicaraguan } \\
\text { workers }\end{array}$ & & & 38 \\
\hline $\begin{array}{l}\text { Becklake et al, } \\
1984(49)\end{array}$ & $\begin{array}{l}\text { South African } \\
\text { service workers }\end{array}$ & & & 31 \\
\hline $\begin{array}{l}\text { Holland \& Reid, } \\
1965 \text { (50) }\end{array}$ & $\begin{array}{l}\text { London workers } \\
\text { aged } 40-49 \text { years }\end{array}$ & 49 & & \\
\hline $\begin{array}{l}\text { Holland \& Reid, } \\
1965(50)\end{array}$ & $\begin{array}{l}\text { English workers } \\
\text { aged } 40-49 \text { years }\end{array}$ & 30 & & \\
\hline $\begin{array}{l}\text { Holland \& Stone, } \\
1965 \text { (51) }\end{array}$ & $\begin{array}{l}\text { US urban workers } \\
\text { aged } 40-49 \text { years }\end{array}$ & 34 & & \\
\hline $\begin{array}{l}\text { Mueller et al, } \\
1971(52)\end{array}$ & $\begin{array}{l}\text { US nonindustrial } \\
\text { community }\end{array}$ & 31 & 42 & 37 \\
\hline $\begin{array}{l}\text { Lebowitz et al, } \\
1975 \text { (53) }\end{array}$ & $\begin{array}{l}\text { US nonindustrial } \\
\text { community }\end{array}$ & 33 & 43 & 38 \\
\hline
\end{tabular}

a Grade 2 dyspnea only.

b Meg Wilcox, Survey of textile mill workers (in jobs unexposed to cotton dust), Nicaraguan Ministry of Labor, unpublished data. 
ty between paraquat exposed and never exposed workers (32), a South African investigation reported abnormal diffusing capacity in 6 of 9 heavily exposed workers (tested because a co-worker died as a result of dermal absorption of paraquat) (55). A follow-up study in which rats were dermally administered sublethal concentrations of paraquat demonstrated medial hypertrophy, lesions identical to those seen in lung biopsies of the 2 most seriously affected workers in the South African study. The authors suggested that acute fulminant paraquat poisoning manifests itself as pulmonary fibrosis, while subacute exposure manifests itself as medial hypertrophy and decreased diffusing capacity, often with normal FVC. Such an effect would explain the high prevalence of dyspnea associated with exposure among the workers in the present study, in the absence of spirometric abnormalities associated with exposure. Alternatively, this pattern might be seen with transient symptoms due to reversible obstructive airway disease not apparent when the patient is free of symptoms. The spirometric results are associated with other known predictors of lung function (height, age, smoking) (table 5). The lack of a more consistent effect of smoking on $\mathrm{FEV}_{1.0}$ is probably the result of the sporadic and often minimal smoking histories of rural workers in Nicaragua.

As with any cross-sectional study design, an inherent limitation to the data in this study is the selection bias which would occur if a person suffered an acute decline in pulmonary health which resulted in a worker becoming disabled. Such cases would be lost to the study, because these workers would no longer be working, and the study would underestimate the effect of paraquat exposure.

Further study is urgently needed to determine whether there is a widespread threat to pulmonary health as a result of occupational paraquat exposure. Follow-up studies of respiratory symptoms should be conducted among workers in Central America and in other cultures to see if a similar dose-response relationship between exposure and dyspnea is observed. It was not possible in this study to take X-rays or to measure diffusing capacity, but such examinations should be done in future studies, if possible with a prospective study design.

\section{Acknowledgments}

We are grateful to Carmen Ibania Kuan, Jamilet Miranda, Fresia Morales, Carlos Quintero, Víctor Ramírez, Lucio Rossini, Teresa Videa, and Venancio Zapata for their assistance with the data collection.

This study was supported by the Swedish Agency for Research in Cooperation with Developing Countries, the Nicaraguan Ministry of Health (Region II), the Department of Preventive Medicine, National Autonomous Uni- versity of Nicaragua in León, the American Friends Service Committee, CARE Nicaragua, and grant P30 ES07048 from the United States National Institute of Environmental Health Sciences.

\section{References}

1. World Health Organization (WHO). International programme on chemical safety: paraquat and diquat. Geneva: WHO, 1984:25. Environmental health criteria 39.

2. Ramasamy S, Tajol Akos NM. A survey of pesticide use and associated incidences of poisoning in Peninsular Malaysia. $\mathrm{J}$ Pl Prot Tropics 1988;5;1—9.

3. Fletcher K. Paraquat poisoning. In: Ballantyne B, Wright J, editors. Forensic toxicology. Bristol: John Wiley, 1974:8698.

4. Naito H, Yamashita M. Epidemiology of paraquat in Japan and a new safe formulation of paraquat. Human Toxicol 1987; $6: 87-8$.

5. Taylor R, Tama K, Goldstein G. Paraquat poisoning in Pacific Island Countries, 1975-1985. New Caledonia: South Pacific Commission Noumea, 1985. Technical paper, no 189.

6. Perriens J, Van der Stuyft P, Chee H, Benimadho S. The epidemiology of paraquat intoxications in Surinam. Trop Geogr Med 1989;41:266-9.

7. Wesseling C, Castillo L, Elinder C-G. Pesticide poisonings in Costa Rica. Scand J Work Environ Health 1993;19:227-35.

8. Proudfoot AT, Stewart MS, Levitt T, Widdop B. Paraquat poisoning: significance of plasma paraquat concentration. Lancet $1979 ; 2: 330-2$.

9. Rose MS, Lock EA, Smith LL, Wyatt I. Paraquat accumulation: tissue and species specificity. Biochem Pharmacol 1976;25:419-23.

10. Stevens JT, Sumner DD. Herbicides. In: Hayes WJ, Laws ER, editors. Handbook of pesticide toxicology. New York (NY): Academic Press, 1991:1356-80.

11. Anderson CG. Paraquat and the lung. Aust Radiol 1970;14: 409-11.

12. Fisher KH, Humphries M, Bails R: Paraquat Poisoning. Ann Intern Med 1971;75:731-6.

13. Fitzgerald GR, Barnville G, Gibney RTN. Clinical, radiological, and pulmonary function assessment in 13 long-term survivors of paraquat poisoning. Thorax 1979;34:414-29.

14. Fock KM. Clinical features and prognosis of paraquat poisoning: review of 27 cases. Singapore Med J 1987;28:53-6.

15. Hettiarachchi J, Fernando SSD. Pulmonary fibrosis following paraquat poisoning. Ceylon Med J 1988;33:141-2.

16. Smith JG. Paraquat poisoning by skin absorption: a review. Human Toxicol 1988;7:15-9.

17. Wesseling C, Hogstedt C, Picado A, Johansson L. Nonintentional fatal paraquat poisonings among agricultural workers in Costa Rica: fifteen case reports. Am J Ind Med. 1997;32:43341.

18. Athanaselis S, Qammaz S, Alevosp G, Koutselinis A. Percutaneous paraquat intoxication. J Toxicol Cut Ocul Toxicol $1983 ; 20 ; 3-5$.

19. Weinbaum Z, Samuels SJ, Schenker MB. Risk factors for occupational illnesses associated with the use of paraquat (1,1'-dimethyl-4,4'-bipyridylium dichloride) in California. Arch Environ Health 1995;50:341-8.

20. Swan AAB. Exposure of spray operators to paraquat. $\mathrm{Br} J$ Ind Med 1969;26:322-9. 
21. Hearn CED, Keir W. Nail damage in spray operators exposed to paraquat. Br J Ind Med 1971;28:399_403.

22. Howard JK. A clinical survey of paraquat formulation workers. Br J Ind Med 1979;36:220-3.

23. Wester RC, Maibach HI, Bucks DA. In vivo percutaneous absorption of paraquat from hand, leg, and forearm of humans. J Toxicol Environ Health 1984;14:759-62.

24. Wester RC, Howard I. Cutaneous pharmacokinetics: 10 steps to percutaneous absorption. Drug Metab Rev 1983;14(2): 169-205.

25. Waight JJJ. Fatal percutaneous paraquat poisoning [letter]. J Am Med Assoc 1979;242:472.

26. Wheater RH. Fatal percutaneous paraquat poisoning [letter]. J Am Med Assoc 1979;242:472.

27. Wohlfahrt EJ. Fatal paraquat poisonings after skin absorption. Med J Austr 1982;1:512-3.

28. Tungsanga K, Israsena S, Chusilp S, Sitprija V. Paraquat poisoning: evidence of systemic toxicity after dermal exposure. Postgrad Med J 1983;59:338-9.

29. Ronnen M, Klin B, Suster S. Mixed diquat/paraquat-induced burns. Int J Dermatol 1995;34:23-25.

30. McElligott TF. The dermal toxicity of paraquat: differences due to techniques of application. Toxicol Appl Pharmacol 1972;21:361-8.

31. Van Wendel de Joode BN, De Graaf IAM, Wesseling C, Kromhout $\mathbf{H}$. Paraquat exposure of knapsack spray operators on banana plantations in Costa Rica. Int J Occup Environ Health 1996;2:294-304.

32. Senanayake N, Gurunathan G, Hart TB, Amerasinghe P, Babapulle M, Ellapola SB, et al. An epidemiological study of the health of Sri Lankan tea plantation workers associated with long term exposure to paraquat. Br J Ind Med 1993;50:25763.

33. Howard JK, Sabapathy NN, Whitehead PA. A study of the health of Malaysian plantation workers occupationally exposed to paraquat. Br J Ind Med 1981;38:110—6.

34. Lings S. Pesticide lung: a pilot investigation of fruit-growers and farmers during the spraying season. $\mathrm{Br} \mathrm{J}$ Ind Med 1982;39: $370-6$.

35. Parkes WR. Occupational lung disorders. London: Butterworths, 1982:403-5.

36. California Department of Food and Agriculture (CDFA). Human health and safety problems occurring in California during 1975 involving employed persons using paraquat CL* agricultural chemicals and feed. Sacramento (CA): CDFA, Worker Health and Safety Unit, 1976. HS-205.

37. Jeyaratnam J, Lun KC, Phoon WO. Survey of acute pesticide poisoning among agricultural workers in four Asian countries. Bull World Health Organ 1987;65(4):521-7.

38. British Medical Research Council (BMRC), Committee on Research into Chronic Bronchitis. Questionnaire on respiratoty symptoms. London: BMRC, 1976.

39. Ferris BG. Respiratory disease. Am Thorac Soc 1978;118(6) part 2:55-9.
40. Quintero G, Anderson K, McConnell R, Hogstedt C. Valores de Reference parafuncion pulmonar en trabajadores nicaraguenses [Reference values for pulmonary function in Nicaraguan workers: in the Nicaraguan-Sweden cooperation program on occupation health research]. Stockholm: National Institute of Occupational Health, 1987-1989.

41. SPSS Inc. SPSS/PC+ V2.0 base manual. Chicago (IL): SPSS Inc, 1988

42. Mantel N, Haenszel W. Statistical aspects of the analysis of the data from retrospective studies of disease. JNCI 1959; 23:719-48.

43. Miettinen OS. Estimability and estimation in case-referent studies. Am J Epidemiol 1976;103:226-35.

44. Maddy KT, O'Connell LP. Occupational illnesses and injuries due to exposure to paraquat as reported by physicians in California in 1981. Sacramento (CA): Department of Food and Agriculture, 1983.

45. Miller A, Thornton JC, Anderson HA, Selikoff IJ. Clinical respiratory abnormalities in Michigan. Chest 1988;94:1187_94.

46. Velazquez AM, Christiani DC, McConnell R, Eisen EA, Wilcox M. Respiratory disease in a textile factory in Nicaragua. Am J Ind Med 1991;20:195 -208.

47. Quintero C, Larios L, Andersson K. Comparison of two questionnaires on respiratory symptoms in a Nicaraguan population: value in diagnosis of chronic bronchitis. Int $\mathbf{J}$ Occup Environ Health 1996;2:88-94.

48. Enarson DA, Christiani D, Emst P, Kennedy S, Mokoetle K, et al. The prevalence of chronic bronchitis: an international comparison. Am Rev Respir Dis 1990;141:A327.

49. Becklake MR, Freeman S, Goldsmith C, Hessel PA, Mkhwelo $\mathrm{R}$, Mokoetle $\mathrm{K}$, et. al. Respiratory questionnaires in occupational studies: their use in multilingual workforces on the Witwatersrand. Int J Epidemiol 1984;16:606-11.

50. Holland WW, Reid DD. The urban factor in chronic bronchitis. Lancet 1965;1:445-8.

51. Holland WW, Stone RW. Respiratory disorders in United States East Coast telephone men. Am J Epidemiol 1965;82:92101.

52. Mueller RE, Keble DL, Plummer, Walker SH. The prevalence of chronic bronchitis, chronic airway obstruction, and respiratory symptoms in a Colorado City. Am Rev Respir Dis 1971; 103:209-28.

53. Lebowitz MD, Knudson RJ, Burrows B. Tucson epidemiologic study of obstructive lung diseases. Am J Epidemiol 1975; 102:137-52.

54. DoPico GA. Report on diseases. Am J Ind Med 1986;10:2615.

55. Levin PJ, Klaff LJ, Rose AF, Ferguson AD. Pulmonary effect of contact exposure to paraquat: a clinical and experimental study. Thorax 1979;34:150-60.

Received for publication: 27 August 1997 